\title{
The Effect of the Chair of School Leadership and Teacher Job Encouragement in the Success of Primary School Teachers
}

\author{
Ismail $^{1 *}$, Happy Fitria ${ }^{1}$, Achmad Wahidy ${ }^{1}$ \\ ${ }^{1}$ Universitas PGRI Palembang, Indonesia \\ "Corresponding author. Email: hadiyantonasuhak096@gmail.com
}

\begin{abstract}
The focus of this research is to identify: (1) the impact of main leadership on the performance of primary school teachers; (2) the effect of motivating teachers to work on the quality of elementary teachers; and (3) the role of primary leadership and encouragement of teachers at the same time on the performance of elementary teachers. The sample of this study consisted of 73 teachers. Data collection techniques are questionnaires and documents. The research data analysis technique used the software application SPSS For Windows Version 21. The findings of the study show: (1) the effect of the headmaster's leadership on performance of primary school teachers in the district of Seberang Ulu II, Palembang City; (2) the influence of inspiring teachers to work partly on the performance of elementary teachers in the district of Seberang Ulu II, Palembang City; and (3) the influence of the key leadership in the district of Seberang Ulu II, Palembang City.
\end{abstract}

Keywords: Principal, Motivation, Teachers Performance

\section{INTRODUCTION}

Teacher success is a learning experience in order to transform current exercises for better practices, such that the learning objectives that were also fixed are well achieved through the learning activity conducted out from the teacher in accordance with the objectives. Rusyan [1] argues that teaching success requires the learning process both in the school and outside of school, as well as other activities such as school administration and learning administration, the implementation of student guidance and services, and the conduct of assessments.

Zahroh [2] defines performance as a reflection of a person's overall goal of achievement. A good teacher works with careful plans so that the planned objectives can be achieved. Differences in performance between one person and another in a work situation are due to differences in the individual's characteristics.

In order for the process to run smoothly, the leader has to treat the individual humanely. Humans, in carrying out their activities, are always influenced by different personalities, such as traits, attitudes, values, desires and interests, thereby affecting their leadership role as well as at work [3]. The effectiveness of schools in improving the standard of education is a joint responsibility between teachers and school principals [4].

Mulyasa [5] that it is through the leadership of the Principal that the School Principal will be able to transfer a number of values, such as focus on groups, support for teachers and employees, tolerance for risk, change criteria and so on, to form a subjective perception of the principles of values that exist within the organization that are consistent with values. The Principal must be able to create a working atmosphere that is supported by his subordinates so that they can always work professionally. Not misuse for personal gain, but to achieve individual objectives within the organization so as to improve the work performance of subordinates and to achieve organizational objectives more effectively and efficiently [6].

Confirmed by Kustimi [7] in relation to the leadership of the principal and the expectations that the school wants to meet, teacher professionalism is the key that needs to be worked on. Teacher professionalism is the work of teachers that is reflected in the design of teaching programs or the planning of teaching, teaching 
implementation, interpersonal relationships and evaluation of learning outcomes.

In connection with the changes, as stated in Mulyasa [5], Uno [8] explains that giving motivation to someone is a link that begins with needs, creates desire, causes tension, causes action, produces decisions. At the beginning of the motivation chain begins with the needs met, the search for ways to meet needs, the goaloriented behavior, the generation of performance, rewards and penalties. Decisions, stress, impulses, search behavior, satisfied needs, and stress reduction are assessed against unmet needs.

Essentially, success is affected by two factors, namely personal characteristics and situational factors. On one aspect, if an individual knows superior efficiency as a way to fulfill his or her needs, he or she it's trying to pursue that direction. Whereas its condition ratio show that success was its result of the relationship among encouragement and practical skills. If the strength is strong but the core skills are weak, the efficiency should be small and if the ability is high but the encouragement is poor, the output should be small or likewise [9].

The results of previous research supporting this research are research conducted by Fitria research [11] where the researchers concluded that it increases the efficiency of teachers requires academic supervision and professional competence of teachers. In this study, the researcher concludes that there are similarities and differences between previous researchers and current research, namely the review of both teacher professionalism and teacher performance. Whereas the difference between previous research and current research lies in the object used as the source of research data and the place of research.

Lian's research [12] shows that the main strategy for developing professional competence is that teachers are assigned to attend education and training, both by the school institution itself and by other educational institutions. The teacher is then asked to train and develop on the basis of his job or position, such as discipline, discussion and motivation. In addition, the principal is also completing the school infrastructure. What this research has in common is that it examines the main strategy. Second, there is an important effect on the personal skills of teachers in the teaching of public high schools in the Tanjung Raja district. Third, there is an important effect on the success of public high school teachers in the Tanjung Raja district of academic supervision and the professional competence of teachers. Third, there is an important effect on the success of public high school teachers in the Tanjung Raja district of academic supervision and the professional competence of teachers.

\section{METHODS}

The research uses a quantitative approach. Sugiyono [13] suggests that quantitative testing methods can be defined as methods of research anchored on the theoretical of positivism being used population and sample research, sequencing techniques are usually performed completely at random, information gathering is using research tools, research methodology is statistical in order to test the hypothesis that has been developed. Samples from this study were 17 teachers teaching at SDN 90 Palembang, 22 teachers teaching at SDN 91 Palembang, 15 teachers teaching at SDN 92 Palembang and 15 teachers teaching at SDN 92 Palembang. The number of samples in this study was therefore 73 teachers in each school. Analysis methods for gathering data with survey questions and reports. The research data analysis technique used the software application program SPSS For Windows Version 21.

\section{RESULTS AND DISCUSSION}

\section{The Partial Influence of Principal Leadership on Teacher Performance}

The test findings carried out through the analysis of the SPSS For Windows Version 21 software application program, the count was 3,977 . Hypothesis test criteria if $t_{\text {count }}>t_{\text {table }}$ then Ha is approved, while if $t_{\text {count }}<t_{\text {table }}$ then $\mathrm{Ha}$ is denied and the $\mathrm{t}$ table is searched for $=5$ percent: $2=2,5 \%$ (2-sided test) with degrees - of - freedom (df) $=\mathrm{nk}$ or $\mathrm{df}=73-2=71(\mathrm{n}$ is the number of samples and $\mathrm{k}$ is the number of independent variables). The results of the two-sided test (significant $=0.025$ ) were obtained for the t table of 3.977. Based on the explanation above, namely $t_{\text {coun }} t=6,088$ and $t_{\text {table }}=3,977$, then $t_{\text {count }}>t_{\text {table }}$ which means that Ho is rejected and $\mathrm{Ha}$ is accepted. It can thus be said that it is partly claimed that the leadership of the Principal does have an effect on results of public elementary school teachers in the district of Seberang Ulu II, Palembang City, and contributes an influence of $18.2 \%$.

\section{The Partial Influence of Teacher Work Motivation for Teacher Performance}

The findings of the experiment were obtained by means of an analysis of the Descriptive statistics For Windows Version 21 software application program. of a $t_{\text {count }}$ of 6.360 hypotheses testing criteria if $t_{\text {count }}>t_{\text {table }}$ then $\mathrm{Ha}$ is accepted, whereas if $\mathrm{t}_{\text {count }}<\mathrm{t}_{\text {table }}$ then $\mathrm{Ha}$ is rejected and table is searched for at much $=5$ percent: $2=2.5 \%$ (2-sided test) with degrees of freedom $(\mathrm{df})=$ $\mathrm{nk}$ or $\mathrm{df}=73-2$ ( $\mathrm{n}$ is the number of samples and $\mathrm{k}$ is the number of independent variables). The results of the two-sided test (significant $=0.025$ ) were obtained for table $t$ of 4.279. Based on the explanation above, i.e. $\mathrm{t}_{\text {count }}=6.360$ and $\mathrm{t}_{\text {table }}=4.279$, then $\mathrm{t}_{\text {count }}>\mathrm{t}_{\text {table }}$ that implies that Hypothesis is rejected and that Accept the 
hypothesis. It can thus be said that, in part, there is an effect of motivating teacher work quality of the teacher in SD Negeri at Seberang Ulu II Palembang City and contributes $20.5 \%$ of the influence.

\section{Simultaneous the Effect of the Chair of School Leadership and Teacher Job Encouragement in the Success of Primary School Teachers}

The results of the research carried out through the analysis of the SPSS For Windows Version 21 software application program, the count was 6,869 . Based on the value of multiple regression coefficients, it is obtained that the value of THitung> TTable, the effect of Principal leadership and teacher motivation work closely on results of Public Elementary School teachers in Seberang Ulu II District, Palembang City with a value of tcount 6.869> ttable 0.690. Thus, in the third hypothesis analysis, it is stated that the effect of primary leadership and the encouragement of teachers to work together on the performance of public elementary school teachers in Seberang Ulu II District, Palembang City, contributes $35.5 \%$.

\section{CONCLUSION}

On the basis of the findings of the research, it could be inferred that: (1) that there's an impact of the leadership of the Principal on the performance of public elementary school teachers in the Seberang Ulu II district of Palembang City; (2) there seems to be an impact on the functioning of service school teachers by promoting teacher work in the Seberang Ulu II district of Palembang City; and (3) there must be a presence of the Principal Leaders and Teachers.

\section{AUTHORS' CONTRIBUTION}

Ismail: designed and performed experiments and analysed data.

\section{ACKNOWLEDGMENTS}

Our deepest gratitude goes to Teachers primary school teachers in the district of Seberang Ulu II, Chancellor of Palembang PGRI University, Director of the Postgraduate Program of PGRI Palembang University and the Education Management Study Program of PGRI Palembang University, who have supported us in doing this extraordinary thing. This project is funded independently. We also want to thank our Education Management friends who helped us a lot in a short time frame to complete this project.

\section{REFERENCES}

[1] Rusyan. (2016). Manajemen Peningkatan Kinerja Guru. Konsep Strategi dan Implementasi Teacher [Performance Improvement Management. Strategy
Concept and Implementation]. Bandung: Remaja Rosdakarya.

[2] Zahroh, A. (2015). Membangun Kualitas Pembelajaran Melalui Dimensi Profesionalisme [Guru Building the Quality of Learning through the Dimensions of Teacher Professionalism]. Bandung: Yrama Widya.

[3] Mulyadi. (2016). Manajemen dan kepemimpinan Kepala Sekolah Management and leadership of the Principal]. Jakarta: Bumi Aksara.

[4] Khasanah, U., Kristiawan, M., \& Tobari. (2019). The Implementation of Principals' Academic Supervision in Improving Teachers' Professionalism in the State Primary Schools. International Journal of Scientific \& Technology Research, 8(8).

[5] Mulyasa. (2013). Menjadi Guru Profesional [Become a Professional Teacher]. Bandung: Remaja Rosdakarya.

[6] Hendarman \& Rohanim. (2018). Kepala Sekolah Sebagai Manajer Teori dan Praktik [Principal as Manager of Theory and Practice]. Bandung: Remaja Rosdakarya.

[7] Kustimi. (2013). Kinerja Kepala Sekolah dan Pengawas dalam Membina Kemampuan Mengajar Guru [The Performance of Principals and Supervisors in Fostering Teacher Teaching Ability]. Tesis. Universitas Pendidikan Indonesia.

[8] Uno, H. B. (2013). Guru dalam Pembelajaran [Teacher in Learning]. Jakarta: Bumi Aksara.

[9] Nanang. (2016). Strategi Pendidikan [Educational Strategy]. Jakarta: Raja Graffindo Persada.

[10] Akpunar, B. (2011). The Effect of Webblog Based Instruction on the Metacognition Levels of Preservice Teachers. "International Journal of Education and Development using Information and Communication Technology (IJEDICT), 2011, Vol. 7, Issue 2, pp. 38-45".

[11] Fitria, H. (2020). Pengaruh Supervisi Akademik dan Kompetensi Profesional Guru terhadap Kinerja Guru di Sekolah Menengah Atas Negeri di Kecamatan Tanjung Raja [The Effect of Academic Supervision and Teacher Professional Competence on Teacher Performance in Public Senior High Schools in Tanjung Raja District.]. Jurnal Manajemen Pendidikan. Volume 9, Nomor 1, Juni 2020. Halaman 104-114.

[12] Lian, B. (2020). Strategi Kepala Sekolah dalam Mengembangkan Kompetensi Profesional Guru. Jurnal Manajemen, Kepemimpinan, dan Supervisi 
[Principal Strategies in Developing Teacher Professional Competence]. Journal of Management, Leadership, and Supervision. Volume 5, Nomor 2, Juli 2020. Halaman 168-174. P-ISSN: 2548-7094 E-ISSN 2614-8021.

[13] Sugiyono. (2015). Metode Penelitian Pendidikan, Pendekatan Kuantitatif, Kualitatif dan $R \& D$ [Educational Research Methods, Quantitative Approaches, Qualitative and $R \& D]$. Bandung: Alfabeta. 